DOI https://doi.org/10.30525/978-9934-26-006-3-32

\title{
ПЕРСПЕКТИВИ ВИКОРИСТАННЯ КОНОПЛЯНОЇ ОЛІЇ ДЛЯ РОЗРОБКИ КОСМЕТИЧНИХ ЗАСОБІВ ПОМ'ЯКШУВАЛЬНОї ДІї
}

\author{
Петровська Л. С. \\ кандидат фармачевтичних наук, доцент, \\ дочент кафедри косметології і аромології \\ Національний фармацевтичний університет \\ Казакова В. С. \\ кандидат фармачевтичних наук, \\ доиент кафедри косметології і аромології \\ Національний фармацевтичний університет \\ Черемісіна В. Ф. \\ кандидат медичних наук, \\ доцент кафедри косметології і аромології \\ Національний фармачевтичний університет \\ м. Харків, Украӥна
}

На шляху євроінтеграції України, фармацевтична та косметична галузі, як складові економіки держави, зазнають значної трансформації. Проходять процеси гармонізації законодавчої, нормативно-регулюючої бази, що, безумовно, впливає на пошук, розробку та впровадження у виробництво конкурентоздатної продукції косметичного сегменту, яка допомагає здійснювати догляд за шкіряними покривами, додатками шкіри людини, підвищувати якість життя, здійснювати профілактику та збереження здоров'я громадян. Накопичений науковий потенціал вітчизняного коноплярства зазнає відновлення на сучасному етапі розвитку, що пов'язано із збільшенням посівних площ промислових конопель та обсягів виробництва лубоволокнистої сировини й насіння. Продовжується активізація наукових установ, що займаються селекцією та насінництвом, впроваджуються технології виробництва не тільки харчових оздоровчих продуктів із вмістом конопляної олії. Так, в харчовій промисловості використовується олія та обрушене зерно конопель; у будівельній галузі здійснюється виробництво композитів, утеплювачів, біоенергетична галузь виробляє паливні брикети та пелети; текстильна промисловість здійснює випуск одежі та кручених 
виробів; розвивається целюлозно-паперова промисловість, що $\epsilon$ екологічною та інші [1, с. 6-10]. Все більш перспективними становляться фармацевтична та парфумерно-косметичні галузі, які займаються розробкою та виробництвом лікарських та косметичних препаратів. Актуальним стає розробка вітчизняної косметичної продукції із вмістом конопляної олії в якості не тільки натурального емоленту, але й біологічно активної домішки для профілактичних та дерматокосметичних засобів по догляду за шкірою при гіперкератозі, атопічному дерматиті, себореї).

Вітчизняними науковцями, зокрема, Інституту луб'яних культур Національної академії аграрних наук України (ІЛК НААН) ще у 2011 році було внесено до Реєстру три нових сорти Вікторія, Гляна та Ніка, в яких вміст тетрагідроканабінолу (ТГК) дорівнює 0, що дозволяє зазначені сорти конопель віднести до категорії ненаркотичних рослин $[2$, c. $46-51,4]$. Крім того, за останні роки зроблено важливий крок на шляху гармонізування нормативно-регулюючої бази до вимог i стандартів $\mathrm{CC}$ - розроблено та затверджено нормативну документацію на готову продукцію: ТУ У 10.4-39224310-001:2019 «Олія конопляна. Технічні умови». Ці досягнення створили передумови не тільки для збільшення посівних площ під даною культурою, чим і відрізнялась Україна до 1913 року та повоєнні роки, але й до науково обгрунтованих досліджень по розробці косметичних засобів для догляду за шкірою та волоссям людини.

Сухість шкіри (ксероз) - це комплекс симптомів таких як: груба текстура шкіри, поява поверхневих зморшок, лущення рогового шару шкіри, підвищена дратівливість, відчуття стягнутості), до появи яких можуть призводити різні причини, однією з яких $є$ порушення власних механізмів регуляції водного балансу. Шкіра здатна самостійно підтримувати рівновагу вологорегуляції та вологоутримуючих систем. Тому, гостра проблема розробки зволожувальних косметичних продуктів полягає не в тому, щоб ввести додаткову кількість води, а у забезпеченні умов для нормалізації власних механізмів регуляції водного балансу. Цю функцію в повній мірі здатні забезпечувати рослинні олії- емоленти.

Рослинні олії - це унікальні натуральні комплекси, що містять важливі для шкіри речовини. Олія конопель сорту «Гляна» містить 54,8 - 55,0 \% лінолевої (Омега-6) кислоти, 16,2 \% олеїнової (Омега-9) кислоти, 14,7 - 14,8 \% альфа-ліноленової (Омега-3) та 2,3 \% гаммаліноленової (Омега-6) кислоти. Співвідношення Омега-6 та Омега-3 в конопляній олії з насіння сорту «Гляна» становить 3,7:1, необхідні для 
збереження й захисту функцій різних клітин організму людини [3, с. 16-19]. Також конопляна олія містить бактерицидні речовини, гліцериди, мікроелементи, вітаміни А, В1, В2, В3, В6, D і Е, антиоксиданти, каротини, фітостероли, фосфоліпіди, мінеральні речовини, включаючи $\mathrm{Ca}, \mathrm{Mg}, \mathrm{S}, \mathrm{K}, \mathrm{Fe}, \mathrm{Zn}, \mathrm{P}$ та інші. У конопляній олії високий вміст хлорофілу (в середньому $2-7$ мг·кг-1), який обумовлює iii зелений колір, а також $є$ природним антиоксидантом [4, с. 8-12]. Конопляна олія має приємний горіховий смак, не має токсичних $\mathrm{i}$ наркотичних речовин. Враховуючи унікальний склад та властивості цієї рослинної олії, нами була поставлена мета-вивчення умов введення конопляної олії для подальшої розробки складу крему пом'якшувальної дії. При виборі основи косметичного крему перевагу було надано емульсії I роду (о/в), в якій вміст олійної фази складав 5-30\%, а водне дисперсійне середовище становило 70-95\%.

Об'єктами наших досліджень були конопляна олія сорту «Гляна», тригліцериди, мінеральна олія та «зелений» натуральний продукт, який в кремах здійснює функцію емульгатору - Емульфарма Екотек (Polyglyceryl-3 cocoate). Вибір емульгатору базувався на його властивостях та перевагах, до яких належать: гіпоалергенність; стабілізація емульсії о/в; можливість самостійного використання без спів-емульгаторів; довготривала пом 'якшувальна та зволожувальна дії на шкіру; здатність надання засобу легкої текстури; утворення не в'язких систем; сумісність з фізичними та хімічними УФ-фільтрами; стабільність у широкому діапазоні $\mathrm{pH}$ : від 4.0 до 8.5; відсутність відчуття липкості при нанесенні на шкіру; можливість використання при низько/низькому температурному режимі виробництва. Враховуючи те, що однією із важливих вимог, що висуваються до косметичних засобів $\epsilon$ безпечність та гіпоалергенність, а високий вміст поверхнево-активних речовин, до яких належить Емульфарма Екотек, може викликати подразнювальну та підсушувальну дії на шкіру, для остаточного складу крему нами було обрано зразок з концентрацією Емульфарма Екотек 4,0\%, а для підвищення в'язкості було використано натуральний згущувач -ксантанову камедь. Спираючись на результати наших наукових досліджень, раціональна концентрація введення ксантану до основи крему становила $0,3 \%$. В розроблених нами експериментальних зразках крему на емульсійній основі була використана конопляна олія в концентрації від $0,25 \%$ до 5,0\%. У досліджувані зразки кремів на емульсійній основі мінеральну олію вводили в концентрації від 0,5\% до 3,0\%. Функцію емолентів у зразках виконували тригліцериди та цетилпальмітат, які найчастіше 
використовуються вітчизняними та закордонними виробниками косметичної продукції для сухого типу шкіри. Дослідні зразки основи крему готували за стандартною технологією: відважений комплекс олій, Емульфарма Екотек, тригліцериди та цетилпальмітат нагрівали на водяній бані до температури $75-80^{\circ} \mathrm{C}$. Паралельно проводили отримання розчину загусника - ксантаної камеді з гліцерином та консервантом при постійній гомогенізації. Потім проводили емульгування за допомогою лабораторного гомогенізатора до отримання однорідної маси. Після повної структуризації дисперсної системи проводили встановлення фізико-хімічних та органолептичних показників згідно вимог ДСТУ 4765:2007 «Креми косметичні». Здійснюється добір комплексу БАР та його ефективної концентрації.

\section{Література:}

1. Wasko J., Kozlowski R., Mankowski J., Mackiewicz-Talarczyk M. The State and the Perspectives of Flax and Hemp Utilization in Poland and in the World. Euroflax. 2002. № 2. P. 6-10.

2. Вировець В.Г., Верещагін I.В. Перші кроки в селекції ненаркотичних конопель на збільшення вмісту олії. Луб'яні та технічні культури: матеріали наук.-практ. конф. (Суми, 11-10 жовтня 2012 р.). Суми, 2012. С. 46-51.

3. Сова Н.А., Луценко М.В., Сніна Н.Ю., Васараб-Кожушна Л.Д. Насіння ненаркотичних конопель - перспективна біологічно активна сировина для харчової промисловості. Хранение и переработка зерна. 2017. № 9 (217). C. 16-19.

4. Vonapartis E., Aubin M.-P., Seguin P. Seed composition of ten industrial hemp cultivars approved for production in Canada. Journal of Food Composition and Analysis. 2015. Vol. 39. P. 8-12. 